The Rhcetic strata of the Birmingham District are everywhere present at the base of the Lias, and appear to be more closely allied petrographically to the strata of that overlying formation than to those of the underlying formation of the Keuper Marls. They are nowhere as much as $50 \mathrm{ft}$. in thickness. They are very rarely exposed, and the sections are usually very indifferent; perhaps the best is that afforded by the railway cutting at Harbury, where the local White Lias is seen, and there is a band of yellowish sandstone which has yielded Estheria minuta. Near Wootten Wawen, shelly limestones occur under the sandstone, and are rich in the usual Rhætic lamellibranchs. Rhætic rocks also occur in the neighbourhood of Leicester (Harrison). The nearest exposure of the Rhætic Beds to the City of Birmingham is that surrounding the small outlier of Lower Lias at Knowle, near Solihull, where the most conspicuous stratum is a yellow micaceous sandstone, with Schizodus cloacinus (Brodie).

The Lower Lias forms a terrace-like expanse of country about eight miles in width, ranging along the south-east edge of the district from Leicester to Stratford, and prolonged in three promontory-like extensions northward into the Keuper Marl area, that which lies east of Droitwich extending within a few miles of the town of Bromsgrove. The best sections of the Lower Lias are those of the railway cutting north-west of Harbury Station, and in the cement quarries of that place, at Rugby, Southam, and Newbold. Fossils are locally abundant, and are well known through the classic researches of the late Rev. P. B. Brodie.

The Middle Lias, or Marlstone series, usually gives origin to a conspicuous scarp overlooking the low ground of the Lower Lias, and attaining its highest elevation in the district at Edge Hill. Some of its strata are locally quarried for building stone.

The distribution of the beds of the Upper Lias, and those of the Inferior Oolite is given upon Map No. 2 (p. 3I5); but they call for no further notice in this place.

\title{
NOTES ON THE PETROLOGY OF THE BIRMINGHAM DISTRICT.
}

By W. W. Watts, M.A., Sec.G.S.

The Midland District will always be classic to the student of rocks because it is the ground where the veteran petrologist Allport began those investigations which he carried out with such success that his descriptions, although the earliest we have, remain unrivalled to this day as models of brief yet full and accurate delineations of rock-structure and composition. From the Wrekin to Charnwood, from Swinnerton Park to Rowley, and 
from pre-Cambrian to post-Carboniferous rocks, he dealt with nothing which he did not thoroughly investigate, always drawing important deductions from his observations, and always searching for new facts and new methods to increase the utility of the microscope as an instrument of petrographic research.

In the few notes which follow I propose to give a short summary of the work of Allport, Waller, Rutley, and Teall,* adding here and there a few points which have come out from my own microscopic observations, founded on specimens collected by Professor Lapworth or myself, or by Mr. Walcot Gibson when he was re-surveying the Lickey Hills for the Geological Survey. I have also had the advantage of confirming many of Allport's conclusions from the study of a set of his own slides now in the possession of Professor Lapworth. It will be most convenient to take the rocks in topographical order, and to deal with the three chief areas of Nuneaton, the Lickey, and the South Staffordshire Coalfield.

\section{The Nuneaton District.}

\section{(a) The Caldecote Rocks (Pre-Cambrian).}

I. The Tutfs.-The composition of the rocks seen in the Tunnel near Caldecote Hill House and the old road above the "Anchor" Inn is andesitic according to Mr. Rutley, and basaltic according to Mr. Waller. The constituent lapilli are much decomposed, but on the whole I incline to the opinion that the contributing rocks were rather basic than intermediate, although neither olivine nor its pseudomorphs have yet been described in them. Quartz is not common, the dominant felspar is plagioclase, iron oxide is abundant, and the amount of chlorite indicates that a good deal of augite must have once been present in the magma from which the lapilli were derived. Mr. Waller describes lapilli of porphyritic basalt, which seem to correspond in composition and aspect with a porphyritic basalt to be immediately described.

2. Quartz-felspar Rock (Quartz-felsite of Waller; Quartzporphyry of Rutley).-This appears to occur rather high up in the-Archæan series, as it is seen close under the basement rocks of the quartzite in Mr. Abel's quarry (Hartsbill Grange), and it also occurs in the "Blue Hole," near Caldecote House. It has very much the appearance of a quartz-porphyry in both localities, but no one has yet succeeded in finding it in a non-brecciated

\footnotetext{
* Allport, Quart. Journ Geol. Soc., vol. xxx, 1874, p. 520 ; vol. xxxv, 1879, p. $3^{67}$.

Waller, Geol. Mag., Decade 3, vol. iii, p. $3^{22}$; Midland Naturalist, vol. viii, p. 26,1885 .

Rutley, Geol. Mag, Decade 3, vol. iii, p. 557 .

Teall, British Petrography (Dulau), London, t888.
} 
condition. In the latter locality the rock exfoliates into spheres, many of them being very large, and surrounded by similar material in a rotten condition. This aspect of the rock resembles the spheroid-bearing wacke which is so often produced by the weathering of basalt, and is so conspicuous a feature in the dolerite of Rowley Regis. 'The disintegrated state of the higher parts of the rock near the contact of the quartzite is suggestive that much weathering had taken place before the deposition of the latter rock, as this weathered condition only extends a few feet below the position of the basal beds of the quartzite, sound rock being met with at the bottom of the cutting. This state of weathering is interesting also in connexion with the phenomena to be immediately described.

3. The Porphyritic Basalt (dark basic rock of Waller; andesite of Rutley).- This rock forms a dyke which traverses the quartzfelspar rock at the entrance to Mr. Abel's quarry, while it also penetrates the quartz-felspar rock in the "Blue Hole," and appears to overlie it. The only porphyritic ingredient in the slides I have seen is plagioclase felspar (determined as labradorite by $\mathrm{Mr}$. Waller) in well-formed crystals which are frequently aggregated together in groups. Mr. Waller has also detected occasional crystals of augite. The ground-mass is like that of an andesitic basalt made up of plagioclase microlites set amongst granules of augite (Rutley thinks this mineral is more likely to be hornblende). The microlites flow in streams round the phenocrysts and the rock has a very characteristic aspect. The grain of the ground-mass varies in fineness, and when at its coarsest an exceptional amount of chlorite, sometimes in good-sized patches which may be relics of augite crystals, is present.

4. Mixture Rocks.-Microscopic slides cut from the junction specimens of this rock with the quartz-felspar rock, proved to Mr. Waller that strings and threads of the basalt penetrated between the grains of the quartz-felspar rock in all directions. The basalt was the later rock and it forms at its junction an intimate mixture with the constituents of the already solidified and disintegrated quartz-felspar rock. When once this fact is recognised it becomes easy to comprehend the complicated relationships between the two rocks in the quarry in question. The result of Mr. Waller's studies, published in 1886, should not be overlooked by those authors (British and Foreign) who are now working on the mixtures of acid and basic rocks.

The Quartz-felspar rock consists of grains of quartz and both orthoclase and plagioclase felspar. The latter are well rounded, but there is no evidence that the rounding has been accomplished in water, for both minerals resemble whole or broken phenocrysts seen commonly in quartz-porphyries, and the quartz exhibits stone cavities and rounded re-entrant angles as if partly re-fused in a quartz-porphyry magma and then broken up, 
either by the disintegration and weathering of a solid mass of igneous rock or by ejection as fragments to form a tuff. I am inclined to think the latter is its real origin, as the rock consists almost entirely of quartz and felspar grains, with very few grains of true quartz-porphyry or its ground-mass in it. Fragments of a genuine igneous quartz-porphyry, however, are found in the succeeding Cambrian Quartzite, perhaps derived from this Caldecote series, as will be seen shortly. The quartz is slightly opalescent, and has a faint bluish tinge.

This disintegrated material was invaded by the basalt and swallowed by it so that for some distance from the junction its constituents are floated in the minutely microlithic ground-mass of the basalt. It is, however, noticeable that the proportion of iron-ore granules in the basalt has considerably diminished, and its porphyritic crystals appear to have been strained out, so that they are rarely present in the mixture rock and are only to be found in the largest basalt strings. In connexion with this point it is important that the porphyritic crystals are more abundant and evident along the junction plane than elsewhere, as was pointed out to me by Prof Lapworth.

The peculiar netted or honeycombed aspect of the quartz in this rock has been noticed by $\mathrm{Mr}$. Waller in his paper.* "I think I have detected a quartz grain in the act of breaking up. It is of irregular shape, and at one side is covered with a network of strings of minute fluid cavities which divide it into roughly polygonal portions. As we pass to the other side of the crystal, however, these become lines of an infiltrated green material, and at the extreme edge a few of the polygonal fragments are quite detached, and separated from the main mass by portions of the ill-defined ground-mass which occurs in this particular specimen." This is fully borne out by the slides which I have examined. The network tends to be hexagonal in the majority of instances, and in the different parts of a single grain the polygonal pieces can be seen to turn more or less on their axes and eventually to become slightly detached, and then to float off into the basalt matrix. In a few instances the quartz is traversed by parallel planes, along which disintegration begins, and is completed by the formation of a series of cross-fractures. Whether these structures were present in the original grain, or were developed for the first time by the intrusion of the basalt, I cannot say, but the separation and brecciation were certainly due to the violence of the basalt intrusion. In parts of the rock the final result of the action has been the complete shattering of the quartz, which is then embedded in very tiny particles in the abundant basalt magma. The rounded, turbid, felspar granules are generally clear and bleached at their margins.

It may be mentioned here that a precisely similar polygonal

*Waller, loc. cit.s, p. $3^{24}$. 
(hexagonal) structure is well seen in the porphyroids of Peldar Tor in Charnwood Forest.

Whether the basalt in the Blue Hole is of the nature of a lava or an intrusion has not been precisely determined, but two points are in favour of the latter interpretation. A definite dyke of the rock is found to pierce the quartz-felspar rock in the more recently opened section of Mr. Abel's quarry, and the action of the basalt on the latter rock in the Blue Hole has been of a violent mechanical character. The act of intrusion, however, seems to have been deliberate, for the basaltic matrix contains well-defined patches of a substance indistinguishable from itself; it would seem from this that the basalt may have solidified in places, and then been broken up and involved with the quartz and felspar fragments in later injections of identical material.

\section{(b) The Cambrian Rocks.}

5. The Quartsites.-The basement beds of the Hartshill Quartzite are of great interest from the fact that, for a considerable thickness, they contain abundant fragments, varying from a pin's head to a pea in size, derived from the underlying Caldecote Rocks. But certain bands are conglomeratic, and consist of pebbles ranging from those not larger than a sparrow's egg up to boulders $3 \mathrm{ft}$. in length. These are generally sub-angular, and most of the known varieties of the Caldecote Rocks have been recognised in them, as well as several other varieties of rocks not at present known from that series.

Quartz grains are always plentiful, and they are generally rounded. Many of them show the polygonal network or parallel cracks and various stages of brecciation. It is, however, clear, that the brecciation and re-cementation have been accomplished previously to the rounding and embedding of the grains in the Quartzite, thus giving additional support to the suggestion that they may have been derived from the quartz-felspar rocks which underly them. When a sufficient number of clean quartz-grains occur in close proximity, secondary growth of silica in optical continuity has taken place, similar to that in the quartzite beds above and below. Rounded felspars and grains of felsitic rock are especially common in the lower bands, and in one specimen there are several grains of quartzporphyry containing phenocrysts of quartz, which, though rounded, never show the polygonal network, parallel structure, or brecciation. Chips of basic rock are also present in these fine-grained rocks, but it is not possible to say with any certainty that they correspond with the basalt of the Blue Hole.

The boulder beds of the Quartzite yield abundant fragments of a quartz-felspar rock macroscopically indistinguishable from that of the Blue Hole. Fragments of fine and coarse tuff are also 
common, and one fragment, which was examined microscopically, corresponds very well with that described from the Caldecote series by Mr. Waller.* It contains abundant felspar in an altered state, a few quartz fragments, lapilli of quartz-felsite, and many lapilli composed of a green rock apparently basic or intermediate in composition. Another fragment consists of much decomposed porphyritic basalt. The porphyritic felspars are similar to those in the basalt of the Blue Hole and of the dyke in Mr. Abel's quarry, and they are similarly grouped. Although the groundmass is obscured by decomposition it is a marked "mikrolithenfilz," like that of the dyke in the Archæan rocks. The main difference from the Archæan specimens that I have hitherto studied is that it contains rather a larger proportion of chlorite and delessite pseudomorphs after augite, but in this character it comes rather nearer to the dyke in Mr. Abel's quarry than to the rock of the Blue Hole.

The higher beds of the Quartzite were described by $\mathrm{Mr}$. Rutley. The growth of new silica appears to bave occurred freely thoughout the rock, especially in its purer portions, thus probably accounting for the high crushing strength of the rock. Grains of glauconite are frequently to be seen in the higher beds, particularly in those associated with the Hyolite Limestone.

6. The Diorites.--These rocks have been so admirably described by Allport and Teall, and figured by the latter from Allport's original slides, that there is not much to add to their descriptions. Porphyritic olivine is frequently present in unmistakable crystals, which, however, are always in the form of pseudomorphs. Hornblende is rarely well preserved in surface specimens, but in those obtained by deep quarrying it is fresh and brown in colour. Augite tends to be a porphyritic ingredient, but felspar is rarely porphyritic, although the crystals are frequently large; orthoclase as well as plagioclase is present. The order of crystallisation is not constant. Olivine, when present, has usually crystallised first, followed by augite when that is present. In many varieties, like those of Marston Jabet, the hornblende occurs in idiomorphic crystals, which are usually elongated, and the long needles can sometimes be seen in hand specirnens, as at Tuttle Hill. On the other hand, at Atherstone and Griff Hollow the structure is ophitic, and plagioclase crystals are embedded in large plates of hornblende. (See Teall, op. cit., Plate xxix.)

Apatite is a frequent constituent, and sometimes a groundmass of calcite and chlorite is present. This is not usually abundant, and the rocks have frequently the idiomorphic texture of the lamprophyres. Indeed, the association of the minerals, the frequent substitution of augite for hornblende, the common idiomorphism of the latter mineral, the infrequence of porphyritic 
felspar, the entire absence of quartz, and the somewhat basic composition of the rocks, all coincide in suggesting that a group of rocks which here and elsewhere occurs so exclusively in normal and sill-like dykes should be placed in the dyke-rock family, called by Rosenbusch Lamprophyres. If this suggestion were adopted, the rocks would be appropriately called hornblendic, augitic, or olivine-bearing camptonites. The occurrence of olivine in rocks of this class is not common, and the entire absence of mica in the area is deserving of remark.

Two varieties of these rocks are deserving of special attention. At Chilvers Coton it is noted by Allport and by Rutley that felspar becomes scarcer than usual, and the first observer describes a variety which consists mainly of hornblende. One of Allport's specimens from Griff Hollow is becoming patchy, being made in places of hornblende with few felspars embedded in it, and in other places of crowded felspars. Associated with the hornblende there is a colourless tremolite. This patchy character becomes extreme at Chilvers Coton railway cutting, as mentioned by Allport. A specimen collected by myself from this locality several years ago is practically a hornblende-picrite, consisting almost wholly of brown hornblende and colourless tremolite, the latter possibly pseudo-morphic after olivine.

A very peculiar variety of the Diorite, forming dykes or sills a foot or so thick, has been discovered by Professor Lapworth penetrating the basal Quartzites in Mr. Trye's quarry (the Anchor Quarry); the variety has been named by him anchorite as a convenient field term. The rock looks and breaks like a conglomerate in which rounded masses of a purple diorite or melaphyre are embedded in a white matrix. On microscopic examination the "pebbles" prove to be spheroids of diorite, in which there is abundance of idiomorphic hornblende much decomposed. These spheroids are embedded in fine-grained veins which consist chiefly of felspar, some being certainly orthoclase ; associated with this is a highly refractive mineral with low birefringence which appears to be zoisite. A little iron-ore is also present in the veins, together with a small amount of interstitial matter in which very narrow, long, microlites of felspar occur. Clearly the rock is of igneous origin, and is an abnormal combination of spheroids and contemporaneous veins resulting from segregation of the magma into basic clots and acid veins.

The rock-type represented by the Nuneaton Diorites is a widely disseminated one. Whenever Stockingford Shales have been penetrated by deep borings, they are found to be pierced by sills of this rock. A similar rock is intrusive in the Archæan rocks of the Lickey, in the Shineton Shales of the Wrekin, in the rocks of the Longmynd itself, and its northern continuation at Bayston Hill, near Shrewsbury, and they are known to pierce the Cambrian rocks in other localities. Similar rocks are intru- 
sive in the Cambrian Quartzites and Limestone of Inchnadamff,* and a hornblende-picrite like that of Chilvers Coton occurs amongst the Bray Head Rocks, at Greystones, $\uparrow$ in Ireland. In none of these localities are the rocks known to penetrate any formation of later than Cambrian age.

\section{The Lickey Hills.}

The Lickey Quartzite has been figured by Teall $t$ and described by several authors, but so far as I am aware the only petrological description of the underlying Barnt Green Rocks hitherto published is contained in the Summary of Progress of the Geological Survey for 1897 , just published. From the brief description of the rocks founded on my own notes and published therein, I extract a few notes by permission of Sir Archibald Geikie. The specimens were collected by Mr. Walcot Gibson during his re-survey of the area, and such field notes as occur in what follows are due to him, and, as will be seen by comparison with the notes on pp. $3 z 8-330$, the microscopic observations agree with the conclusions drawn by Prof. Lapworth some years ago from the field evidence.

I. The Barnt Green Rocks.-These are chiefly pyroclastic rocks though some of them consist of pyroclastic material which has been deposited in water. \$ "The pyroclastic rocks are mostly tuffs made out of fragmental felspars, amongst which orthoclase predominates over plagioclase; there are also fragments of an orthophyre-like rock. Quartz fragments are practically absent from the typical tuffs, but when the felspars begin to be rolled and rounded as well as broken, and the tuff has evidently been laid down in water, a little quartz is generally present. One example, which may be called a volcanic grit, such as may have resulted from the wearing down of lavas and tuffs," or from the dropping of the material of orthophyre-tuff in water, "contains more grains of ferro-magnesian minerals as well as particles of orthophyre and orthophyre-tuff. The ground mass of all these rocks appears to have undergone silicification. Many of the rocks have been shattered," by earth movement, "and filled with veins of calcite and quartz." One of the rocks, rather more massive than the rest, has somewhat the appearance of an intrusive mass in the field, but "the microscopic character of the rock, while not disproving this supposition, lends it no additional support, for the rock does not differ in any marked degree from those described as orthophyre-tuffs, except that it is finer-grained, and the large and obviously clastic felspars are absent. A dark purplish-blue shale from this group is well laminated, and

\footnotetext{
* Teall, Geol. Mag., Dec. 3, vol, iii, 1886, p. 346.

+ Watts, Rep. Brit. Assoc, 1893, p: 767 .

" "British Petrography," Plates xlv and xlvi.

$\$$ Op. cit., p. 68 .
} 
contains angular grains of quartz, felspar, and white mica embedded in an opaque ground-mass. A set of plagioclasebearing igneous rocks penetrates the Barnt Green Group. The only original minerals left are plagioclase and iron ores, the former are arranged as in an ophitic rock; the secondary minerals, chlorite, serpentine, and epidote, do not make it clear whether the original ferro-magnesian mineral was hornblende or augite, but the general likeness in structure and appearance, to the diorites [camptonites] of Nuneaton, suggest that the rocks should be classed with the diorites. They have not yet been found to penetrate the quartzites. Another igneous rock is a brecciated porphyritic basalt, which may be an intrusion or a lava-flow, but the field evidence does not appear to be sufficient to decide the question." This last rock is somewhat like the porphyritic basalt which occurs in the "Blue Hole" at Caldecote.

2. The Quartzite.-- "The main constituent is quartz in rolled grains, round which new quartz has been deposited in optical continuity, so that the constituents of the rock are now closely interlocked. Many of the varieties are rich in grains of felspar, and a few grains of glauconite are to be found in most of them. This last fact is suggestive, when it is remembered that the Hollybush Sandstone (Comley Sandstone), which in Shropshire overlies the [Cambrian] quartzite, is rich in grains of glauconite. Traces of bedding are generally to be seen [even in microscopic slides], and there is no evidence of crushing in the mass of the rock, although the slicken-sided surface of some of the joint-planes indicates that considerable movement must have taken place." The secondary silicification of the rock reaches its highest degree where the movement has been considerable, and it is from such localities that the specimens of quartzite usuaily figured and described from the area have been taken.

\section{The Dolerites and Basalts of the South}

Staffordshire Coalfield.

In very numerous localities in England, Ireland, and Scotland there occur intrusive basic rocks of later date than the greater part of the Coal Measures, and the South Staffordshire Coalfield is no exception. Intrusive sills are found throughout the field, and in those places where the sills are thick and massive the rock becomes coarser-grained. Rowley Regis is the largest mass of dolerite in the Coalfield, and it is a laccolite intruded into the southward continuation of the Dudley anticline. The cover has been entirely removed, and the mass is now only in contact with its sole. Other large masses appear at the surface at Barrow Hill and at Pouk Hill, near Walsall. The sills occupy a good deal of the surface of the ground near Wednesfield. These rocks formed 
a portion of the subject of Allport's memoir on the British Carboniferous Dolerites.

Porphyritic olivine is almost invariably a constituent of the rocks; it is frequently quite fresh, but in surface specimens it is often converted into pseudomorphs of serpentine, calcite, or zeolite, with or without specular iron. The original discovery of the nature of these changes by Allport has had a wide-reaching effect on our knowledge of the serpentine rocks. Augite is a still more abundant constituent; it is generally coloured, pale brown, yellowish, puce-purple, warm-brown, or green tinged, and is frequently slightly pleochroic. Indeed, it is the variety of augite supposed to be titaniferous, a supposition which, I believe, has never been verified. Plagioclase felspar is very abundant, and orthoclase occurs sparingly in many varieties. Magnetite and ilmenite are both of common occurrence, and in the coarser varieties apatite occurs. Hornblende is of rather rare occurrence. In most varieties, but especially in the coarser types, interstitial zeolites are to be found, and in some examples there are not less than three distinct zeolites, of which analcime appears to be one.

The structure is very variable. At Pouk Hill the rock is ophitic, but patchy, and there would not appear to have been any very considerable interval between the crystallisation of the felspar and that of the augite. At Rowley microporphyritic rocks are common, plagioclase, orthoclase, and olivine occur as phenocrysts in a ground-mass composed of idiomorphic, rod-like, augite, and crystalline magnetite, embedded in felspar. At Hailstone Hill, part of the Rowley mass, a very beautiful, coarse-grained rock is occasionally met with which at once attracts attention from the large six-sided plates of ilmenite found in it. The felspars are large and well-formed, and often include small augites, while larger crystals of augite, well-formed and idiomorphic, are frequently found outside them, and embedded, like them, in interstitial matter. Olivine is present, and the plates of ilmenite appear in the slides as rods or blotches. Apatite is usually abundant. While the order of crystallisation in the Rowley Rag is generally the reverse of that usually found in dolerites, Allport found specimens in which the relationship of augite and felspar was that of a micropegmatite (or a variety of centric structure), the two substances crystallising simultaneously so that large areas of each polarise together. Allport also discovered and briefly described a set of remarkable red contemporaneous veins from Hailstone Hill, which were subsequently more fully dealt with by Waller.* These consist chiefly of orthoclase felspar, as shown by the twinning and the refractive index, with sparingly distributed green augite and magnetite, set in inter- 
stitial matter in which Waller recognised colourless glass. A brown fibrous zeolite also occurs interstitially, and to this the colour of the veins is apparently due. Mr. Waller's analysis of the veins shows that they contain $5^{\circ} 3$ per cent. of silica, $5^{\circ}$ O of potash, and $5^{\circ} 2$ of soda, as against $48.8, \mathbf{r}^{\circ} 9$, and 3.7 respectively in the normal rock. The veins have a specific gravity of $2 \cdot 58$, while the normal rock gave Mr. Waller a specific gravity of 279 . A specimen tested by myself gave $2 \cdot 76$ for the normal rock, and 2.78 for the coarse ilmenite-bearing rock previously described.

In an old quarry near the north-east side of the mass a very beautiful columnar structure is revealed, and in one of the great excavations at Rowley itself the columns are singularly starchlike, although of very large size. Spheroidal structure is very common, the spheroids being enclosed between more or less rectangular joints in the same fashion as is seen in perlitic texture. An excellent example, which Prof. Bonney has made classical, is figured by him from Turner's Pit, and the original of his drawing appears to be still visible.* The weathering of the basalt has already been remarked on, and it extends deep into the mass, reducing it to a sandy-looking product, in which are embedded the more durable of the spheroids, the outer layers of which, when partly rotted, form shaly-looking " brows" round the augenlike spheroids.

The smaller sills are of finer-grained basalt, known as green rock by the coal-miners, which passes readily into white trap near the contact with coal-seams.

All these rocks in South Staffordshire and similar rocks at the Titterstone Clee in Shropshire, in Leicestershire, and elsewhere, are intrusive into the upper Coal-measures, and so cannol be of earlier date than very late Carboniferous. A very similar rock was described by Allport, at Swinnerton Park, near Trentham, in North Staffordshire, and Kirkbyt has shown that it is a dyke intrusive into the Trias. If all these rocks are of the same age, the date of intrusion must be post-Triassic.

But Jukes, in his Survey Memoir on the South Staffordshire Coalfield, points out that the Rowley mass partakes in the movements which have affected the Coalfield, thus placing an upper limit to the age of the intrusion if the date of the movement can be ascertained.

A comparison of the dolerites with the well-known Tertiary lavas of Antrim, and with the abundant Tertiary dolerite dykes which occur all over the North of Ireland, in Scotland, the Isle of Man, and elsewhere, shows that there are many features in common between the two types. The character, colour, and pleochroism of the augite, and the inconstant relation of the two

\footnotetext{
* Bonney, Quart.Journ. Geol. Soc., vol. xxxii, 1876, p. 151 .

† Kirkby, Trans. N. Staffs. Vat. Field Club, vol, xxviii, I894, p. 129.
} 
chief constituents are characters linking the two types, while the freshness of many of the minerals, and especially of the olivine, gives the rock a very new aspect. It would be scarcely possible for a petrologist to discriminate the coarse varieties of rock seen at Hailstone Hill from that of Killala Bay, in Sligo, on the one hand, or from the coarse dolerites of Portrush and Fair Head on the other." Again the finer grained dolerite lavas of the Giant's Causeway, and the Tertiary dykes of Lisnaskea and elsewhere in Ireland would be very difficult to distinguish from the normal rocks of Pouk Hill and Rowley.

When we recollect that some of the faults which bound the South Staffordshire Coalfield traverse Jurassic rocks, one is tempted to ask whether it may not be possible that those movements which post-date the Rowley Rag in the South Staffordshire Coalfield are in reality of Tertiary date. If not, the similarity of pre-Tertiary and post-Tertiary volcanic rocks is closer even than Allport suspected, when he was struggling for a recognition of the identity of the rocks of these different ages.

\title{
THE ANCIENT GLACIERS OF THE MIDLAND COUNTIES OF ENGLAND.
}

\author{
By W. Jerome Harrison, F.G.S.
}

As far as their glacial phenomena are concerned, the Midland Counties offer to the geologist one of the most interesting and important fields of research in the British Isles. And this for three main reasons :

(I) Three great glaciers met here.

(2) The district contains examples of the terminal and lateral moraines, and also of the "fringe" + of these giaciers.

(3) But litcle detailed work has as yet been done in mapping out the precise courses and limits of the great streams of ice by which the district was formerly invaded.

\section{No Submergence.}

It may be said at once that there is no evidence in the Midlands of any great depression since the close of the Mesozoic Era. The so-called "sea cliffs," "coast lines," etc., can be shown to be but the ordinary results of sub-aerial denudation; the finely-stratified, often false-bedded, gravels, sands, and loams of the surface deposits are for the most part the results of the subglacial, englacial, and supra-glacial drainage-systems of the glaciers. Some loams were deposited in ice-dammed glacial lakes, while

* Guide to the Collections of Rocks, etc., belonging to the Geological Survey of Ireland. Dublin, 1895 , pp. $5 \mathrm{I}$ and 78 .

t I apply the term "fringe" to the dubious region which lay just at or in front of the original margin of the ice. It is usually occupied by gravels and sands, the results of the melning of the ice. "The glacier-ice sometimes made temporary excursions into the "fringe" in some regions, but it was never permanently glaciated. 